\title{
BREACHING THE PEACE: STRUGGLES AROUND MULTILINGUALISM IN SWITZERLAND
}

\author{
(Accepted in revised form 22 May 2006)
}

\begin{abstract}
Swiss multilingualism has been suggested as a model for a unified Europe. In this country, the territoriality principle and political subsidiarity have supported a discourse on multilingualism for the purpose of 'mutual understanding'. However, a conflict has recently upset the cohabitation of four national languages in Switzerland, resulting partly from conflicting responses to the spread of English in Swiss society. This paper discusses the struggle around the weighting of national languages versus English in educational language policy. The dominant discourse on multilingualism has been confronted with a globalising ideology, where competence in English is seen as a commodity to be acquired early. An economically powerful canton, Zurich, introduced English as a first additional language in primary school in 1998, triggering what has come to be known as Sprachenstreit, or 'language strife'. An apparent compromise may not be stable as language issues have now been subjected to a referendum. The implications of the Swiss case are discussed in the light of European language policy.
\end{abstract}

KEY WORDS: discourse, educational language policy, English as a foreign language, European Union, multilingualism, national languages, Switzerland, symbolic capital, Territoriality

\section{INTRODUCTION}

Why Switzerland? The Cambridge political scientist Jonathan Steinberg used this question as the title of a study of the 'special case' (Sonderfall) of a smugly self-sufficient nation at the crossroads of Alpine transit routes, a rich stable democracy, the calm eye of the storm which was the European 20th century. Eight years after the second edition of this book was published (Steinberg, 1996), there is some consensus in this country and abroad that much of what made it a Sonderfall has evaporated: Switzerland has its historical scandals (misuse of Jewish assets and refugee crisis in the Second World War), its business crashes (Swissair), and its political polarisation (rise of the far right and the Greens). More to the 
point, the country has its very own language conflict, if only in a typically miniature version.

This paper attempts:

1. to characterise the apparent peaceful cohabitation of language communities as a drôle de paix, a peculiar kind of peace;

2. to define and describe the discourses that confront each other in a struggle over identities and legitimate linguistic repertoires;

3 . to look at the main site of the language strife, namely languages in education, and the role of the national languages and of English as a foreign, intruding language;

4. to raise some questions that may be of wider relevance for European language policy.

The conclusion draws attention to the risks of entrusting language policy principally to the system of education and the limitations of the territoriality principle in a federalist state. It also discusses the implications of a tendency towards stressing global and local concerns, with the middle space, the nation state as an imagined community (Anderson, 1983), slowly dissipating.

\section{Background: The Construction of Multilingualism}

The political and cultural construction of the Swiss nation state has, for a century, played its cards to its advantage. Not only has the Swiss economy profited immensely from political stability, but the country and its government have shrewdly used a politics of alliances, and often non-alliances, to maintain an advantageous position internationally. A rugged agricultural backwater with few natural resources except for rocks, woods, snow and water, Switzerland used to be a country from which impoverished people emigrated to other continents. Up until 1880, it chalked up an annual net migration loss of up to $4 \%$. From the late 19 th century to the 1980s, the Swiss economy, based to a considerable extent on exports and asset management, has seen a boom that has propelled the country to the top of the list of rich nations. Arguably, the fact that Switzerland was not involved in any armed conflict throughout the World Wars has contributed to this wealth. At the same time, Swiss enterprises, diplomats and politicians were deeply embroiled internationally, also during times of war (Tanner, 1986).

At the base of the Swiss nation state lie the twin principles of subsidiarity and grass-roots democracy (Kälin, 1998). The political 
system of checks and balances assigns the various layers of the state a high degree of representation and participation with instruments such as referenda and citizens' and cantons' initiatives. There has been a widespread belief that Switzerland is somehow a different and privileged member in the chorus of nations - so much so that the majority of voters deemed it was not necessary or opportune for the country to become a member of the United Nations until 2002.

In one respect, Switzerland's self-constructed political identity differs from most other European nations. Since its first modern constitution of 1848 it has revolved around the co-existence of four linguistically distinct communities in one geographic and political space. Squaring political power and evening out perceived or real grudges among the German-, French-, Italian- and Romanshspeaking groups has occupied the agenda for a century and a half (Büchi, 2000; Grin, 1997).

Living at the periphery of three large speech communities has offered three of the Swiss language groups a number of advantages such as communicationally greased trade relationships with their respective neighbours and cultural rejuvenation through participation in transnational exchange. The term Willensnation ('the willed nation') is and was used in the discursive space of the nation-building process to stress the volitional force that binds the communities together. Being part of a traditionalist discourse, the term begs the question of what energises the motivations to 'will a nation', or, in other words, to keep imagining a community from the present into the future. In this imagined multilingual and politically 'neutral' nation state, balance has been a key construct (e.g. in many decades of coalition governments and in the delegation of educational policy to cantons). Balance, as something constructed and maintained, is always a matter of equilibrating various forces. The hegemonic ideology has tended to assign the national languages particular traditional territories and to bank on the concept that members of the language communities will not need actually to meet while they can still "live the image of their communion" (Anderson, 1983: 6).

\section{Language Peace and the Dominant Federalist Discourse ON Multilingualism}

The principle of territoriality is central to the question of national cohesion (Papaux, 1997). Switzerland consists of 26 can- 
tons (with an average size of $1600 \mathrm{~km}^{2}$ ) which have a great deal of autonomy, for instance in most matters of education. In a nutshell, linguistic territoriality means that the cantons decide on the official language in which they deal with citizens and run their schools.

In a 1996 national vote, an article (Article 116) was approved in the constitution dealing with language rights and obligations of the federal state. Article 116 does not say anything about territoriality, although the principle had been upheld by a number of Federal Court decisions. In 2000, the constitution underwent a general revision, in which the languages article, although very recent, was changed considerably (cf. Table 1).

Most significantly, the parliament inscribed the principle of territoriality in Article 70, Paragraph 2. Why in 2000, and not in 1996? Why is there now a teleological formulation, translated in the English version as "[i]n order to preserve harmony between linguistic communities", linked to the preservation of the "traditional territorial distribution of languages"? Why, incidentally, are there semantically differing representations of the same referent in the various official language versions of the text? German Einvernehmen ('mutual agreement or comity') is rendered as harmonie in the French version while the Italian text speaks of guaranteeing linguistic peace (per garantire la pace linguistica) as if from south of the Alps the situation appears more perilous. ${ }^{1}$ The line of argument in this paper will be that something significant and disturbing must have happened in the years between the first and second articulation of these constitutional articles.

In the discursive space that opens around the theme of languages and society in Switzerland, three interlinked but distinct clusters can be discerned, which I will exemplify and discuss in turn. They can be seen as engaging in different projects:

1. Building and maintaining the nation state around cultural diversity and mutual understanding.

2. Preserving niches and opportunities for regional and local development, often in response to centralist tendencies.

${ }^{1}$ The four versions of the relevant passage in Article 70 are as follows: German: "Um das Einvernehmen zwischen den Sprachgemeinschaften zu wahren"; French: Afin de préserver l'harmonie entre les communautés linguistiques"; Italian: "Per garantire la pace linguistica"; Romansh: "Per mantegnair l'enclegientscha tranter las cuminanzas linguisticas". 
TABLE 1

Comparison of language articles in the Swiss constitution, 1996 and 2000.

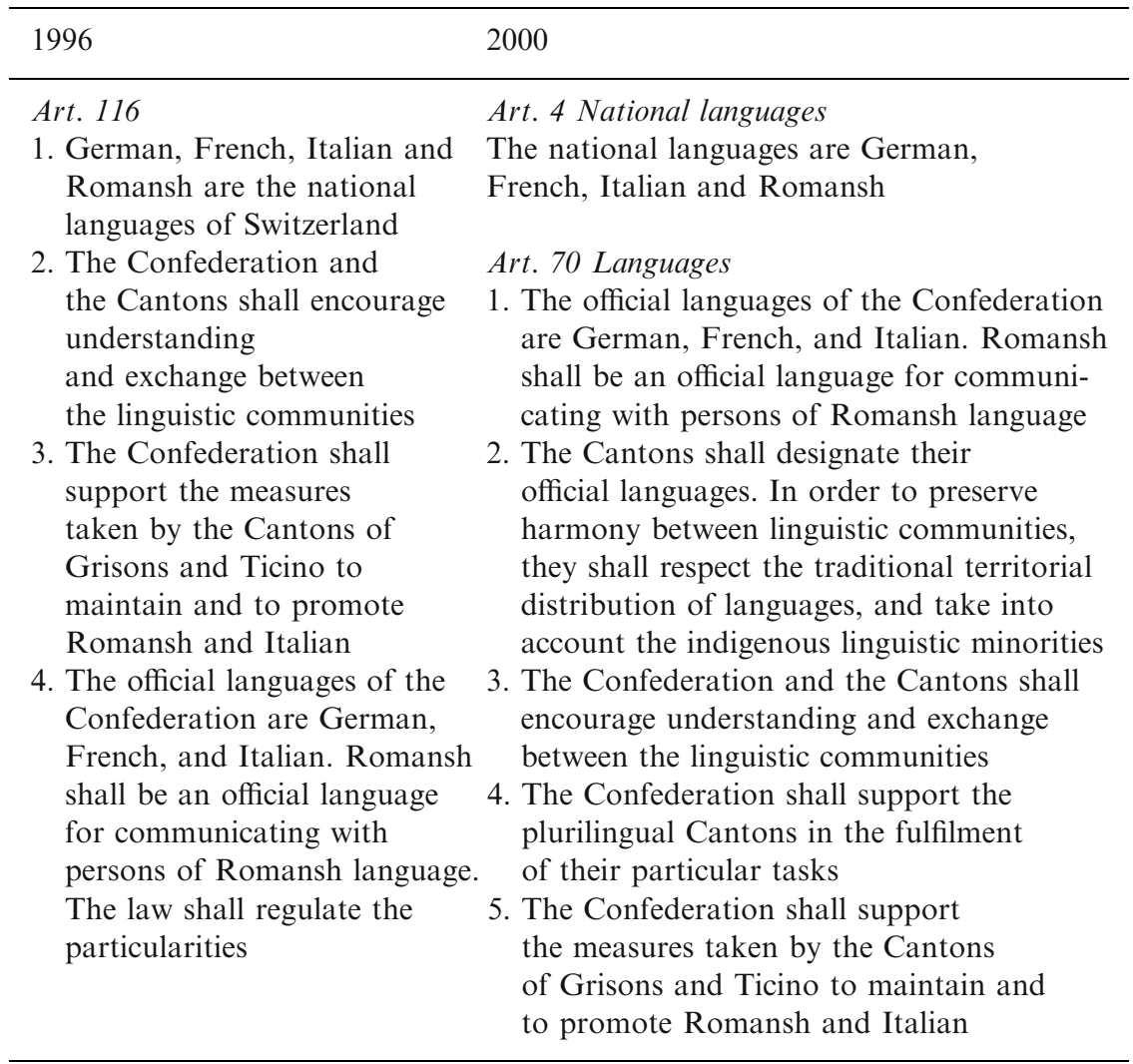

3. Participating in transnational exchanges and fulfilling the needs of citizens in new educational and occupational configurations.

The first cluster of discourse formations is grouped around the notion of a threat to the harmony and peaceful cohabitation of linguistic communities. This theme was particularly evident in a debate which unfolded over four issues of the journal Schweizerische Zeitschrift für Politische Wissenschaft in 1996/97 (see Grin, 1997). The discussants engaged with the question as to how the problems and issues of linguistic and cultural diversity can be managed. I have attempted to filter out from this debate common assumptions and concerns of those voices who profess to maintaining linguistic diversity and balance in the Swiss nation state (see Table 2). 
In summary form, these are some of the principal elements of what I shall call the confederate discourse of multilingualism: ${ }^{2}$

- There is little direct spontaneous interaction among speakers across the language borders. The smaller minorities are neglected by the German-speaking majority and the larger Frenchspeaking minority (Extracts 1,2).

- Language peace is threatened both by ethnification (especially Swiss Germans using dialect and refusing to speak and write the standard form of German), and globalisation, which is linked to the increasing use of English in the world of business, science and entertainment $(3,6,7)$.

- Mutual understanding and dialogue among the language groups is essential, but the rewards offered are mainly symbolic $(3,5,6)$.

- Public education is entrusted with the objective of good multilingual citizenship. The second national language is L2, the language to be learnt second after the mother tongue $(1,6,7)$. It is also called langue partenaire.

- Using English as a lingua franca within Switzerland leads to an impoverishment of the relations between the language communities $(6,7)$.

The confederate discourse on multilingualism has its roots in enlightenment and modernism. According to this set of values and beliefs, a humanist project is under way towards the creation of a better life for individuals. Its worldly form of citizenship and statehood is based on rational principles of choices and constraints and develops in parallel with progress in technology, wealth distribution and workplace quality. In this discourse, education is the major site for the creation of the multilingual citizen. Learning one other national language apart from one's native tongue is a prerogative and duty of the citizens of this multilingual state. In a country with firm linguistic borders and a territorial notion of language, school language learning appeared to be, speaking with Foucault (1977), a disciplining exercise in the service of national cohesion. The impression prevailed abroad of a contentedly multilingual country with a large proportion of multilingual citizens.

While the modernist confederate discourse on multilingualism is deeply concerned with the relationship between territory and languages,

2 Although I have chosen the adjective 'confederate' on the basis of the official name of the Swiss state (Schweizerische Eidgenossenschaft or in Latin Confoederatio Helvetica), I do not want to suggest that the confederate discourse coincides with official Swiss language policy. 
TABLE 2

Extracts from texts relating to the discourse on multilingualism.

\begin{tabular}{|c|c|}
\hline Quotation & Translation by this author, DS \\
\hline $\begin{array}{l}\text { 1. Nous formulons par conséquent le } \\
\text { postulat que le sous-développement } \\
\text { des connaissances linguistiques des } \\
\text { autres communautés helvétiques est } \\
\text { essentiellement fonction d'un non- } \\
\text { besoin dans le quotidien (Knüsel, } \\
\text { 1997) }\end{array}$ & $\begin{array}{l}\text { 1. As a consequence, we formulate } \\
\text { the hypothesis that insuffi- } \\
\text { ciently developed knowledge } \\
\text { of Switzer-land's other lan- } \\
\text { guages is essen-tially a func- } \\
\text { tion of the absence of a need } \\
\text { [for these languages] in every- } \\
\text { day life }\end{array}$ \\
\hline $\begin{array}{l}\text { iz gibt es de facto zwei } \\
\text { achen, die deutsche und } \\
\text { che, } \\
\text { er die Existenz zweier } \\
\text { prachen, der italienischen } \\
\text { anischen, } \\
\text { Fremdsprachen nur } \\
\text { je nach Wetterlage (sprich: } \\
\text { e) } \\
\text { (Ghisla, 1997) }\end{array}$ & $\begin{array}{l}\text { 2. In fact there are two majority } \\
\text { languages in Switzerland, the } \\
\text { German and the French } \\
\text { language, whose speakers per- } \\
\text { ceive the existence of two } \\
\text { minority languages, Italian and } \\
\text { Romansh, as well as further } \\
\text { foreign languages, only in } \\
\text { passing and depending on the } \\
\text { weather conditions (i.e. their } \\
\text { interests) }\end{array}$ \\
\hline $\begin{array}{l}\text { 3. In dem Masse, in dem sich die } \\
\text { religiös-kirchlichen, die klassenmässigen } \\
\text { und parteipolitischen } \\
\text { Milieus der vorausgegangenen } \\
\text { Epoche der Kultur- und Klassenkämpfe } \\
\text { auflösen, wächst die Sprachkultur } \\
\text { zum bestimmenden Kohäsions- } \\
\text { und Identifikationselement in der } \\
\text { Schweiz heran. Die } \\
\text { Sprachengemeinschaften } \\
\text { nehmen in steigendem Masse das } \\
\text { Gepräge von Sprachenblöcken } \\
\text { an und zerstören das Netzwerk, } \\
\text { das die Grundlage des multikulturellen } \\
\text { schweizerischen Staatwesens bildet } \\
\text { (Altermatt, 1997) }\end{array}$ & $\begin{array}{l}\text { 3. At the same time as the reli- } \\
\text { gious-ecclesiastical, the class- } \\
\text { based and the party-political } \\
\text { networks of the previous era of } \\
\text { culture and class struggles are } \\
\text { dissolving, language culture } \\
\text { emerges as the determinant } \\
\text { element of cohesion and iden- } \\
\text { tification in Switzerland. The } \\
\text { language communities are } \\
\text { increasingly adopting the char- } \\
\text { acteristics of linguistic blocs } \\
\text { and are thus destroying the } \\
\text { network which forms the basis } \\
\text { of multicultural Swiss state- } \\
\text { hood }\end{array}$ \\
\hline $\begin{array}{l}\text { 4. Die latente Ethnisierung ist mit einer } \\
\text { schleichenden Belgisierung verbunden } \\
\text { [...]. Damit ist } \\
\text { gemeint, dass sich auch in der } \\
\text { Schweiz langsam Sprachenblöcke } \\
\text { heranbilden. }\end{array}$ & $\begin{array}{l}\text { 4. Latent ethnification goes hand } \\
\text { in hand with an insidious } \\
\text { Belgification, [...] meaning } \\
\text { that in Switzerland too, } \\
\text { language blocs are starting to } \\
\text { take shape. }\end{array}$ \\
\hline
\end{tabular}


TABLE 2 (Continued)

\begin{tabular}{|c|c|}
\hline Quotation & Translation by this author, DS \\
\hline $\begin{array}{l}\text { Mit Hilfe der Massenmedien ge- } \\
\text { winnen die sprachregionalen } \\
\text { Grenzen an Bedeutung und lassen } \\
\text { einen Sprachenkorporativismus } \\
\text { nach belgischem Vorbild entstehen } \\
\text { (Altermatt, 1997) }\end{array}$ & $\begin{array}{l}\text { With the help of the mass media, } \\
\text { regional language borders are } \\
\text { beginning to gain significance and } \\
\text { are responsible for developing a } \\
\text { linguistic corporatism along the } \\
\text { lines of the Belgian example }\end{array}$ \\
\hline $\begin{array}{l}\text { 5. Da die Probleme der gegenseitigen } \\
\text { Verständigung mit zahlreichen } \\
\text { gesellschaftspolitischen Fragen } \\
\text { verknüpft sind, muss die Stärkung } \\
\text { des nationalen Zusammenhalts im } \\
\text { föderalistischen Staatswesen von } \\
\text { allen staatlichen Ebenen als } \\
\text { dringliche Aufgabe wahrgenom- } \\
\text { men werden (Reichenau, 1997) }\end{array}$ & $\begin{array}{l}\text { 5. Since the problems of mutual } \\
\text { comprehension are tied up with } \\
\text { numerous societal questions, the } \\
\text { strengthening of national } \\
\text { cohesion in the federalist state } \\
\text { must be tackled by all layers of } \\
\text { the state as an urgent task }\end{array}$ \\
\hline $\begin{array}{l}\text { 6. Wer in einer mehrsprachigen } \\
\text { Gesellschaft die Sprache der and- } \\
\text { eren beherrscht, kann nicht nur } \\
\text { Informationen austauschen, sond- } \\
\text { ern geht auf die anderen ein, akz- } \\
\text { eptiert sie, und nimmt ihre Kultur } \\
\text { aktiv wahr. Das Modell einer lin- } \\
\text { gua franca (z.B. Englisch) für eine } \\
\text { infranationale Kommunikation } \\
\text { übersieht diese für eine Gemein- } \\
\text { schaft lebenswichtige Vora- } \\
\text { ussetzung (Ghisla, 1997) }\end{array}$ & $\begin{array}{l}\text { 6. Whoever masters the language of } \\
\text { the others in a multilingual } \\
\text { society, cannot only exchange } \\
\text { information, but also give } \\
\text { attention to the others, accept } \\
\text { them and become actively aware } \\
\text { of their culture. The model of a } \\
\text { lingua franca (e.g. English) for } \\
\text { intranational communication } \\
\text { overlooks this precondition which } \\
\text { is vital for a community }\end{array}$ \\
\hline $\begin{array}{l}\text { 7. Le recours à l'anglais, langue } \\
\text { étrangère à l'ensemble des } \\
\text { locuteurs, est indubitablement un } \\
\text { constat d'échec. S'il permet d'eng- } \\
\text { ager un dialogue d'égal à égal entre } \\
\text { élites, il n'en est pas moins réduc- } \\
\text { teur des spécificités des autres cul- } \\
\text { tures (Knüsel, 1997) }\end{array}$ & $\begin{array}{l}\text { 7. Resorting to English, a foreign } \\
\text { language to all speakers, is } \\
\text { undoubtedly an acknowledgement } \\
\text { of failure. Even if it allows elites to } \\
\text { engage in a dialogue among } \\
\text { equals, it nevertheless reduces the } \\
\text { specific features of the other cultures }\end{array}$ \\
\hline
\end{tabular}

it is curiously silent about economic and class questions. As from 1975, progress was made in establishing the second national language as a subject on the primary school curriculum. The implementation of this reform absorbed energies so much that the problem of access and educational mobility among immigrant children and adults was partly overlooked and partly masked by optimistic notions of the rich tapestry of languages offered by these families. However, if in 
Italian-speaking Ticino Italian immigrants' children do worse than their Swiss colleagues (EDK/CDIP, 2001), the difference must be due to something other than mere first language competence; rather, it must be sought in a combination of knowledges about powerful ways of communicating and interacting in schools, and thus the reproduction of social difference through schools.

Towards the end of the millennium, voices from within the confederate discourse sounded a more alarmist note, supported by amplification in the media. In the same vein, the discourse has become more self-reflexive and self-critical. What is striking in the period of discontinuity beginning in the late 1990s is that doomsaying has tended to outweigh the promise of rewards for learning a second national language.

\section{Definition and Analysis of Language Strife}

It is now time to study the question as to what role English plays in Switzerland. In doing so, we have to be very careful not to equate a language with a power or a discourse and fall victim to the same sort of essentialism that has marred the cultural politics of languages in Switzerland.

'English' in Switzerland and elsewhere is not a unified phenomenon to confront the world and its speakers with ineluctable force (Brutt-Griffler, 2002; Pennycook, 2001). We should be careful to view the language, the desire for it, the learning and acquisition that lead to competence, and the communications in this language in its many varieties as a web of complex ties with manifold forces pulling its threads. Above all, we should look at the people learning, using and speaking about English.

There are two distinguishable clusters in the discursive space of multilingualism that pick up on the increasing significance of using and learning English. On the one hand, there is and always has been a degree of assertiveness in smaller cantons in the east and in mountainous areas of Switzerland to dissociate themselves from what the federal state has deemed necessary. In this discourse, which might be called federalist (or anti-centralist), the emphasis is on opportunities for citizens and their children to find jobs in regions weak in infrastructure and service industries and to prevent internal migration (brain drain) from the periphery to the centres such as Zurich and Basle. Proponents of this discourse have increasingly started to criticise the confederate project, claiming 
that teaching the second national language in primary school has been ineffective and unpopular. On the other hand, as the director of education of the smallest canton, Appenzell Innerrhoden, asserts, English is the language that is linked to opportunity and popular choice. He cites the phenomenon of parents enrolling their children in private English courses:

Die Volksschule, die dem Grundsatz der Chancengleichheit verpflichtet ist, musste reagieren und Englisch für alle Kinder anbieten. (Schmid, 2000)

Public (i.e. state, or publicly funded) schools, which are obliged to promote the principle of equal opportunity, had to react and offer English for all children.

Schmid goes on to state that primary school French is "not a success story" and defends his canton against a centralist solution dictated by the federal administration (einer vom Bund dekretierten einheitlichen Sprachenlösung). It is interesting to note that directly economic considerations are not mentioned in this article although studies such as Grin's (1999) had clearly shown up direct financial benefits for employees mastering English in German-speaking Switzerland. However, as the language-related workplace statistics from the Swiss census (Lüdi \& Werlen, 2005) show, in many more peripheral workplaces neither the second national language nor English are used very frequently. ${ }^{3}$

It is thus not surprising that the third cluster of discourse formations which can be discerned originates from urban regions with strong export-oriented economies. The argumentative base for this project, which has led to far-reaching changes in Swiss educational language policy, is rooted in a view of linguistic resources as a commodity (Heller, 2003) rather than a symbolic effort towards national cohesion. In order to understand the thrust of this discourse, which I will provisionally call 'globalising', we need to follow and understand its trajectory from conception to radical change.

In 1998, a few months before a "Comprehensive Languages Concept" was to be published by a national working group that was intended to coordinate and move early language learning to Year 3 of the primary school, the director of education of the canton of Zurich, the economically most powerful region with $1 / 7$ of the country's population, launched an experimental project which was aimed at testing out several innovations for the public

${ }^{3}$ In Zurich, 34\% of the respondents claim they use English regularly in the work place, and $22 \%$ say they use French, while the charts for Appenzell Innerrhoden display about $12 \%$ for English and $8 \%$ for French use in the workplace (cf. also Andres et al., 2005). 
schools of this canton, among them the introduction of English from the first grade of the primary school onwards (Age 6). The justification was that English was to be seen to a large extent as "the language of the communication society", and mastery of IT skills and of English as well as the ability for life-long learning were "key qualifications" for tomorrow's society (Schulprojekt 21, 1998:3). The new forms of language teaching that were trialled in Schulprojekt 21 between 1998 and 2003 and are currently being implemented strive to make schools more amenable to the needs expressed by business and upwardly mobile families. The figure 21 in the project name was chosen to denote its relation to the 21 st century.

What is significant about the project is that it was to be implemented without any consultation among the 25 other cantons, ${ }^{4}$ and that its language political thrust constituted a clear disruption in educational language policy. This new globalising discourse did not go through a lengthy process of federal consensus-seeking; for those who articulated and supported it, there was a self-evident chain of reasoning: national language policy qua learning a second national language has had its run and it has failed at least partly; parents want English, the economy wants English. In this sense, it is a bottom-up, populist discourse as opposed to the more elitist confederate discourse of multilingualism. On the other hand, it plays on dominant motifs such as globalisation, the need for transnational integration and opportunities for wealth creation. It is also noteworthy that the experimental introduction of English followed a novel approach where the new language served as a means of communication about school subjects (content and language integrated learning). It was accompanied by a scientific evaluation (Büeler, Stebler, Stöckli, \& Stotz, 2001) that was supposed to yield insights into the feasibility of the approach and the benefits of the new order of language learning, with English before French.

Shortly after the project began rolling with 100 experimental classes and before the final evaluation report was completed, the government of the canton of Zurich decided definitely to introduce English to the primary school (Year 3, later moved to Year 2), while maintaining French from the fifth year. The decision was met

${ }^{4}$ The Swiss Confederation does not regulate public primary and secondary education on a national level. The cantons are sovereign in this domain, but they attempt to coordinate the 26 educational systems through the EDK/CDIP (conference of the cantonal directors of education). 
with severe criticism in politics and the media because it was seen as a demonstration of raw power. The traditional consensus politics had suffered a blow by this so-called Sprachenstreit (language strife). In the wake of Zurich, Appenzell Innerrhoden introduced primary school English from Year 3 and moved the onset of French classes to secondary school (Year 7), at the same time increasing teaching time for the second national language slightly. ${ }^{5}$

\section{Fragmentation or Consensus?}

After a long and troublesome process of discussion and procrastination, the coordinating body of the cantonal ministers of education (EDK/CDIP) decided in March 2004 to recommend to the cantons that second/foreign language learning should be intensified by moving the onset into the lower grades of the primary while at the same time leaving it to the cantons to determine which languages were to be learnt first and second. The model known as $3 / 5$ stipulates that the first additional language should be on the curriculum no later than Grade 3 (age 9) and the second additional language by Grade 5. The Common European Framework (Council of Europe, 2000) and the European Language Portfolio are used to help ensure that competences in the second national language and English are comparable at the end of mandatory schooling.

What will the Swiss educational language map look like a few years hence? The further away from the German-French language border and the more monolingual people are, the clearer the call for English. Eastern and central Switzerland will start with English, bilingual Berne, German-speaking Basle and other cantons along the language border favour 'French first', while French-speaking cantons have little choice but to prioritise German; it would be difficult to tease apart the economic from the political in this discourse of minorisation. The conundrum for Basle is perhaps an indication of the tension present in much of Switzerland: the city is dependent on multinational pharmaceutical corporations, part of the Upper Rhine bilingual and trinational region, within an hour from French-speaking Switzerland, committed to the Swiss democratic project, yet often more progressive and urban than much of central Switzerland. Clearly, the three discourse configurations, viz. the confederate, the federalist and the globalising positions with

\footnotetext{
5 This is true for one stream of secondary school; in the other, French is an option.
} 
respect to school language learning, are not divided as neatly into territories as the national languages themselves.

Returning to the notions of territoriality and subsidiarity, what is at stake quite practically at this moment is not the cohesion of the nation, but the easy mobility of families with school children from one canton to another with potentially differing curricula. If all parties agree on comparable competences at the end of mandatory schooling for the second national language and English, and if tomorrow's children start to learn these languages at earlier ages and remain successful, then little is in effect lost, and the question of which language is to be learnt first is really a red herring.

However, the apparent compromise solution covers up a real power struggle, which will not go away easily. Significantly, in a number of cantons, popular initiatives have been launched to limit to one the number of foreign languages to be taught in primary school and to start teaching the second language at secondary school only (from Year 7, as in the Appenzell model). The main argument is that learning two additional languages imposes excessive demands on many young learners and that the first priority should be to master the standard language (Standard German, used as a medium of instruction in a diglossic situation, cf. Rash, 1998). It is interesting to note the term sprachlastig that has been coined in this debate; it suggests that the curriculum is overloaded with language subjects and that many children will be overtaxed, specifically those who are having to learn German as a second language. Significantly, these initiatives have only been launched in cantons where a decision for English as a first foreign language has been made or is imminent. Their proponents thus appropriate the discourse of globalisation and turn it against the confederate discourse:

Der Europarat propagiert aus Mobilitätsgründen die Ausbildung zur Mehrsprachigkeit. Für die Mobilität genügt es aber absolut, wenn alle Jugendlichen Englisch sprechen und verstehen können. Eine zweite Fremdsprache (Französisch oder Italienisch) bringt keine entscheidenden Mobilitätsvorteile, ist aber für unser Staatsverständnis sinnvoll. (Sek I CH, no date)

The Council of Europe propagates education towards multilingualism for reasons of mobility. For the purpose of mobility, it is absolutely sufficient if all young people can understand and speak English. A second foreign language (French or Italian) does not provide any advantages in terms of mobility, while it is sensible for our understanding of the state. (Translation by DS)

The lobbyists go on to argue that secondary school French should be reserved for the best students. Thus, while on the one hand 
English is associated with a valuable resource that allows access to promising marketplaces, the obligation to learn a national language is not linked to any opportunities for using it. Adherents of the confederate discourse can claim with some justification that pushing French into the secondary schools is an attack on the second national language and "harmony among the linguistic communities".

It will be interesting to witness these coming plebiscites. ${ }^{6}$ The fact that voters will have a say on the number and distribution of languages on the school curriculum underlines a common conundrum of language policy in democratic states: popular choices may well conflict with what the political elite sees as the best way of maintaining a democratic multilingual project. What may result is a typically Swiss checkerboard landscape where different cantonal communities define educational language needs differentially based on contested conceptions of economic, cultural and political capital.

At the same time there is an initiative pending on the national level that aims to inscribe the priority for the second national language into the constitution (Initiative Berberat). If and when it comes to the vote, the cantonal policies will already have been implemented; national language policy-making and the confederate discourse may well turn out to be ineffectual amid a tension between globalising and localising concerns.

\section{ConClusions}

It has been argued above that something decisive must have happened between the national vote on the new constitutional language article and its revision by the parliament in 1999/2000. In the climate of that year, the act of adding a purposive passage about maintaining harmony among the language communities reads like a last-ditch attempt to patch up the confederate discourse. As there are no major demographic movements which would endanger the French- and Italian-speaking communities, and as the threat to Romansh would be evident even without these words, the addition of the passage can only be interpreted as a reaction to a perception that harmony and understanding are on the wane. However, as the debate about which language to teach first suggests, the question is pegged onto the main field of activity left to language policy, that of education.

\footnotetext{
${ }^{6}$ Up-to-date information on the developments can be accessed http:// www.sprachenunterricht.ch
} 
The failure of language policy and the confederate discourse on multilingualism in Switzerland to create a clear mission and a rationale for action is not the result of bad intentions or sheer neglect, but it is the outcome of a reliance on traditional values and hegemonies. The territoriality principle, the ostensible care for autochthonous minorities, the shared history of half a millennium of relatively peaceful bi- and multilingualism and the division of power into ever smaller relations due to subsidiarity: all of these factors have worked together to form a complacency liable to underestimate the dynamism of late modernity (Giddens, 1991).

Switzerland at the turn of the millennium is caught in the midst of a discursive struggle about languages, multilingualism and language in education, a struggle that goes to the heart of our understanding of a grass-roots democracy and the peaceful cohabitation of several languages in a modern state. I have tried to work out competing discourses, which clash on the question of language policy for education; but they are evidence of multifarious formations that cut across sociolinguistic, social, political and cultural categories. The discourse of communicative globalisation has exposed the traditional scarcity of interaction between compatriots and the use of additional languages by a few, tendentially elite groups or bilingual families. The tense relationship between national languages locked into their territories, evoking a condition of isolation and separateness, and a language, English, which many people see as offering economic and symbolic advantage gets played out by the cultural and educational politics of language, with schools having to bear the brunt of the struggle.

Refreshingly for a society prone to sweep controversial issues under the carpet, media and citizens, politicians and publicists have engaged in the conflict, but some of them have tended to zero in on the surface issue of which language should be learnt first by primary school children. Language strife can be highly productive if it highlights the contested nature of desirable language resources. Together with a broader shift in the discourses on the challenges that the democratic project Switzerland faces, it has warned everyone that the resources for consensus are finite, and are in fact likely to be exhausted soon.

Educational language policy in Switzerland resembles remarkably the European two-languages policy (European Commission, 1995, 2003, 2005). The decisions by the European Union with 
respect to multilingualism have provoked less debate although the agenda for change is in fact substantial. In 10 countries of the EU-15 (the pre-2004 EU) two languages are in fact compulsory in general secondary education, but in some cases the distance in onset between the first and the second foreign language is longer than in the Swiss 3/5 model, or a second foreign language is compulsory for only 1 or 2 years. At present only three EU member states have implemented a similar scheme with two additional languages taught in compulsory education before the age of 12 (Luxemburg, Estonia and Lithuania; cf. Eurydice, 2005). As Erling and Hilgendorf (this volume) suggest, official policy on both the European and national levels remains vague and tends to refrain from specifying which two languages people should learn because "there is a tacit understanding that the first of these two languages is going to be English". Struggles such as in Switzerland are unlikely to arise as long as the second foreign language (the partner language) can easily be confined to that elitist niche that it has traditionally occupied. As in the Swiss case, any language apart from English that is not rooted in a local bilingual community may be cast in a token role as a nod towards the nation state or Europe and its imagined ideals.

In Switzerland, there is a growing sense of urgency around language issues and a fresh awareness that issues of power, dominance and minorisation are at stake, and that linguistic capital mobilises power. Instead of a discourse of power retention, which emanates from the ways in which federal institutions talk about legitimate languages and repertoires, we need a discourse of persuasion which allows individuals themselves to see more clearly the choices they have and the sorts of resources they would like to build up in order to be able to do the things they want in the spaces they will occupy professionally and privately. In other words, citizens need to become more aware of the symbolic and cultural capital they have and they will want to acquire with further learning. If they accept the proposals and offerings of language learning as valid, they are more likely to appropriate their personal learning objectives and repertoires and to make them part of their identities. If they find fault with the proposals, they will resist them and, in a sense, diminish their own chances of coming up with legitimate repertoires. In this process we need to be aware of the double-edged sword of what Bourdieu has called the profit of distinction (Bourdieu, 2001). 
In that respect the local languages concept that the city canton of Basle has produced is innovative in that it is explicitly related to the transnational economic and cultural space of the Upper Rhine (Germany, France, Switzerland). It refers to a regional strategy of the 'Oberrheinkonferenz' which prioritises the neighbouring language (French/German) over English and bases itself on the recognition that the labour market and the international competition for head office location favour this kind of repertoire, for which there are real opportunities for use.

What we need to focus on increasingly are the actual opportunities for use and the validation of the use of languages in meaningful situations. As in Bourdieu's economic framework capital is only symbolic if and when it is known or recognised as capital, competence is only legitimate if it is known or acknowledged in acts of performance.

\section{AcKnowledgements}

Part of the work on which this article is based has been funded by the Swiss National Science Foundation in a project entitled "Multilingualism, identities and language learning in Swiss schools and communities" (Number 731021). I would like to thank two anonymous reviewers and the editors for their helpful comments.

\section{REFERENCES}

Anderson, B. (1983). Imagined communities. London: Verso.

Andres, M., Korn, K., Barjak, F., \& Glas, A., Leukens, A., \& Niederer, R. (2005). Fremdsprachen in Schweizer Betrieben. Nordwestschweiz: Fachhochschule Solothurn.

Altermatt, U. (1997). Viersprachige Schweiz: anderthalbsprachig plus Englisch? Schweizerische Zeitschrift für politische Wissenschaft, 3(6), 136-143.

Bourdieu, P. (2001). Langage et pouvoir symbolique. Paris: Seuil.

Büchi, C. (2000). "Röstigraben". Das Verhältnis zwischen deutscher und französischer Schweiz. Zürich: Verlag Neue Zürcher Zeitung.

Büeler, X., Stebler, R., Stöckli, G., \& Stotz, D. (2001). Lernen für das 21. Jahrhundert? Externe wissenschaftliche Evaluation, Schlussbericht. http:// www.sprachenunterricht.ch/praxis2.php (last viewed March 2006).

Brutt-Griffler, J. (2002). World English. A study of its development. Clevedon: Multilingual Matters. 
Council of Europe (2000). The Common European Framework for Languages: Learning, Teaching, Assessment. Cambridge: Cambridge University Press.

EDK/CDIP (2001). Italienische Schülerinnen und Schüler in der Schweiz/Des élèves italiennes et italiens en Suisse/Allieve e allievi italiani in Svizzera. Bern: EDK/CDIP.

European Commission (1995). White paper on education and training. Towards the Learning Society. Brussels: European Commission.

European Commission (2003). Promoting language learning and linguistic diversity: An Action Plan 2004-2006. Brussels: European Commission.

European Commission (2005). A new framework strategy for multilingualism. Brussels: European Commission.

Eurydice (2005). Key data on teaching languages at school in Europe. Brussels: Eurydice.

Foucault, M. (1977). Discipline and Punish: The birth of the Prison. Translated from the French by Alan Sheridan. New York: Vintage Books.

Ghisla, G. (1997). Die Minderheiten brauchen ein Mindestmass an Reziprozität. Gedanken zu einer mehrsprachigen und multikulturellen Schweiz. Schweizerische Zeitschrift für politische Wissenschaft, 3(1), 149-156.

Giddens, A. (1991). The consequences of modernity. Stanford: Stanford University Press.

Grin, F. (1997). Language policy developments in Switzerland: Needs, opportunities and priorities for the next few years. Schweizerische Zeitschrift für politische Wissenschaft, 3(2), 108-113.

Grin, F. (1999). Compétences et récompenses. La valeur des langues en Suisse. Fribourg: Editions universitaires.

Heller, M. (2003). Globalization, the new economy and the commodification of language and identity. Journal of Sociolinguistics, 7(4), 473-492.

Kälin, W. (1998). What makes decentralised government work? Lessons from Switzerland. Essays on Constitutional Law, 27, 1-19, Nepal Law Society.

Knüsel, R. (1997). Les rapports interlinguistiques suisses restent dominés par les crispations. Schweizerische Zeitschrift für politische Wissenschaft, 3(1), 143-149.

Lüdi, G. \& Werlen, I. (2005). Sprachenlandschaft in der Schweiz. Eidgenössische Volkszählung 2000. Neuchâtel: Bundesamt für Statistik.

Papaux, A. (1997). Droit des langues en Suisse: état des lieux. Schweizerische Zeitschrift für politische Wissenschaft, 3(2), 131-134.

Pennycook, A. (2001). Critical applied linguistics. A critical introduction. Mahwah, NJ: Erlbaum.

Rash, F. (1998). The German language in Switzerland. Multilingualism, diglossia and variation. Bern: Peter Lang.

Reichenau, C. (1997). Eine Debatte, doch kein Dialog. Schweizerische Zeitschrift für politische Wissenschaft, 3(4), 100-108.

Schmid, C. (2000). Dank Frühenglisch der Zweiklassengesellschaft vorbeugen. Neue Zürcher Zeitung, 27.09.2000, p. 15.

Schulprojekt 21 (1998). Entwicklungs- und Finanzplan. Zürich: Bildungsdirektion des Kantons Zürich.

Sek I CH (no date). Thesenpapier. Erste und zweite Fremdsprache an der Volksschule. http://www.lvo.ch/pdf/2004-01/Thesenpapier-Sek1-LCH.pdf. (Last viewed in March 2006).

Steinberg, J. (1996). Why Switzerland? 2nd edition. Cambridge: Cambridge University Press. 
Tanner, J. (1986). Bundeshaushalt, Währung und Kriegswirtschaft. Eine finanzsoziologische Analyse der Schweiz zwischen 1938 und 1953. Zürich: Limmat-Verlag.

\begin{abstract}
ABOUT THE AUTHOR
Daniel Stotz is a Professor in the Department of Languages at the Zurich University of Teacher Education. He has research interests in applied linguistics, language policy and foreign language didactics. He is also co-editor of the journal Babylonia. Address for correspondence: Zurich University of Teacher Education, Department of Languages, LAA 017, Lagerstrasse 5, CH-8090 Zurich, Switzerland. E-mail: daniel.stotz@phzh.ch
\end{abstract}

